\title{
Plasma alkaline phosphatase isoenzymes in hepatobiliary disease
}

\author{
A. O. AFONJA' ${ }^{1}$ AND D. N. BARON 2 \\ From the Department of Chemical Pathology, Royal Free Hospital, London
}

SYNOPSIS By cellulose acetate or acrylamide gel electrophoresis it is possible to separate these alkaline phosphatase isoenzymes from serum: [anode] fast liver, slow liver, placenta/Regan, bone, intestine, bile [cathode]. Heat or chemical inhibition can confirm the differentiation.

Normal adult serum always contains slow-liver isoenzyme, and sometimes bone isoenzyme: the latter is always present in serum of children. In hepatobiliary disease slow-liver isoenzyme was always increased: intestinal isoenzyme appeared in many cases of cirrhosis (of blood groups B and 0) but fast-liver and bile isoenzymes were occasionally seen in miscellaneous cases. The findings in other diseases included Regan isoenzyme in six out of 45 cases of malignant disease.

Four major isoenzymes of alkaline phosphatase (orthophosphoric-monoester phosphohydrolase: EC 3.1.3.1) have been known for some time and can be easily separated in normal and abnormal serum: they are produced respectively by liver parenchyma, placenta, intestinal mucosa, and osteoblasts (Arfors, Beckman, and Lundin, 1963; Green, Cantor, Inglis, and Fishman, 1972; Fishman, Bardawil, Habib, Anstiss, and Green, 1972). The predominant liver isoenzyme is 'slow' or ' $\alpha_{2}$ '. More recently, a second liver isoenzyme ('fast' or ' $\alpha_{1}$ ') has been demonstrated in the serum of some patients with hepatobiliary disease but its origin is uncertain (Rhone and Mizuno, 1973; Fritsche and AdamsPark, 1972). The separate isoenzyme found in bile arising from duct cells may occasionally be detected in serum (Kaplan and Rogers, 1969). The isoenzyme present in chyle has properties similar to those of intestinal isoenzyme (Inglis, Fishman, Stolback, Warshaw, and Fishman, 1972). Regan isoenzyme represents the related isoenzymes with properties similar to placental isoenzyme that may be produced by malignant tissues (Fishman, Inglis, Stolbach, and Krant, 1968).

There is uncertainty about the diagnostic value of determining serum alkaline phosphatase isoenzymes. We have therefore investigated the iso-

\footnotetext{
${ }^{1}$ Present address: Department of Chemical Pathology, Lagos University Teaching Hospital, Nigeria.

${ }^{2}$ Correspondence to Professor D. N. Baron, Department of Chemical Pathology, Royal Free Hospital, London NW3 2QG.

Received for publication 13 August 1974.
}

enzyme patterns in a variety of hepatobiliary disorders and in some other conditions for comparison. The opportunity has been taken to compare the acrylamide gel (Smith, Lightstone, and Perry, 1968@ Canapa-Anson and Rowe, 1970) and the cellulose acetate strip (Fritsche and Adams-Park, 1972 methods of separating isoenzymes.

\section{Materials and Methods}

Normal sera were obtained from fasting laboratory staff and from specimens of child inpatients with unrelated complaints such as tonsillitis. Abnormal sera were obtained from fasting inpatients, and occasionally from outpatients, of the Royal Free Hospital. Diagnoses were based on clinical assessment and on full laboratory and radiological studies, supplemented when appropriate by liver biopsy.

Serum was separated as soon as possible. The sera were first analysed for total alkaline phosphatase activity by the kinetic method of Moss (1966), adapted by Stevens and Thomas (1972), in order to determine the amount of serum needed for electrophoresis. On cellulose acetate $6 \mu$ l of serum con- N taining less than $20 \mathrm{KA}$ units/dl was used, while $3 \mu \mathrm{l}$ was sufficient for serum containing higher $\mathrm{N}$ activities. On acrylamide gel $25 \mu l$ of serum con- $\omega$ taining less than $30 \mathrm{KA}$ units/dl was used: if 30-60 KA units/dl, $20 \mu \mathrm{l} ; 60-90 \mathrm{KA}$ units/dl, $15 \mu \mathrm{l} ; \stackrel{\circ}{\subset}$ 90-120 KA units/dl, $10 \mu \mathrm{l} ; 120-150 \mathrm{KA}$ units/dl, $5 \mu \mathrm{l}$. The serum was diluted with aqueous sucrose solution $(20 \mathrm{~g} / \mathrm{dl})$ if the activity exceeded $150 \mathrm{KA}$ units/dl. 
Portions of the sera were frozen at $-20^{\circ} \mathrm{C}$ until analysed for isoenzymes: they were all analysed within one week of obtaining the specimens. This delay did not alter the isoenzyme distribution.

\section{INHIBITION}

Since the heat-stable placental and Regan isoenzymes have a mobility similar to but distinguishable from the bone isoenzyme, their presence was confirmed by repeating the electrophoretic separation after destroying the bone isoenzyme by heat at $65^{\circ} \mathrm{C}$ for 30 minutes (Aoba, Hariu, and Yamaguchi, 1967). Differentiation of intestinal from liver isoenzyme was confirmed by its sensitivity to $5 \mathrm{mmol} / \mathrm{l}$ concentration of L-phenylalanine, while bone and liver isoenzymes were characterized by their sensitivity to $25 \mathrm{mmol} / \mathrm{l}$ concentration of L-homoarginine (Green et al, 1972).

\section{ELECTROPHORESIS}

For electrophoresis on acrylamide gel (borate buffer $\mathrm{pH} 8 \cdot 8$; preparation buffer tris-citrate $\mathrm{pH}$ 8.8 , Smith et $a l, 1968$ ) and on cellulose acetate (tris-barbitone buffer pH 8.8, Fritsche and AdamsPark, 1972) the substrate was $\beta$-naphthyl phosphate and the stain Fast Blue RR. Acrylamide electrophoresis was performed in the cold room at $4^{\circ} \mathrm{C}$ for six hours at $90 \mathrm{~V}$, cellulose acetate electrophoresis at room temperature for $18 \mathrm{~min}(0 \cdot 3 \mathrm{~h})$ at $200 \mathrm{~V}$.

\section{Results}

COMPARISON OF SEPARATION PROCEDURES The figure shows the distribution of isoenzymes in relation to serum proteins. The analyses are of sera from typical clinical cases. The order of separation is (anode): fast liver, slow liver, placental Regan, bone, intestinal, bile (origin): (cathode).

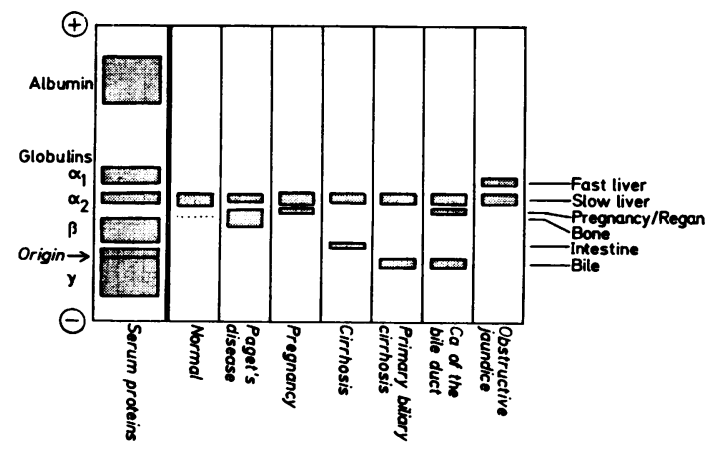

Fig Electrophoretic separation of alkaline phosphatase isoenzymes of human serum in health and disease compared with the pattern of normal serum proteins.
The acrylamide gel method separates the bone (osteoblastic) and 'slow' liver $\left(\alpha_{2}\right)$ isoenzymes more clearly but the bile isoenzyme cannot be identified with certainty. Results are otherwise identical with either method. The ease of setting up and the short time required for adequate electrophoretic separation make the cellulose acetate strip a suitable method for the routine analysis of alkaline phosphatase isoenzymes in serum and there has been no difficulty in detecting individual increases in liver and bone isoenzymes.

PATTERN IN HEALTh AND DiseASE (TABLE I) Liver isoenzyme (slow $\alpha_{2}$ ) was universally detected. Normal adult serum usually showed only the liver band, but in $13 \%$ of samples a slight bone band was also detected. In growing children the bone band was always seen, the total serum alkaline phosphatase values being between 15 and $28 \mathrm{KA}$ units/dl. In normal pregnancy the placental band was first seen at 15 weeks, and in the last trimester was detected in $28 \%$ of samples: placental isoenzyme was always found when the totalalkaline phosphatase exceeded $20 \mathrm{KA}$ units/dl. One each of five cases of normal twins, of three cases of toxaemia, of six cases of hypertension, and of three cases of postmature pregnancy showed a placental band, the total alkaline phosphatase activity being in the range of 20-27 KA units/dl.

All patients with hepatobiliary disease who were studied had raised serum total alkaline phosphatase. In cases of cirrhosis $22 \%$ showed the intestinal band. Fast $\left(\alpha_{1}\right)$ liver isoenzyme was seen in a few cases of infective hepatitis, obstructive jaundice, or primary biliary cirrhosis but not in cirrhosis. The bile isoenzyme occurred only occasionally, with or without the fast liver isoenzyme, in primary biliary cirrhosis and in carcinoma of the bile duct.

Of the 38 cases of intestinal disease examined, six had a raised total alkaline phosphatase (17-21 KA units/dl). An intestinal band was seen in one case of malabsorption syndrome due to coeliac disease, with a total alkaline phosphatase of $18 \mathrm{KA}$ units/dl.

All patients with bone disease had an increased bone band when there was an increased total serum alkaline phosphatase and increased osteoblastic activity, as did some patients with chronic renal failure: the one fracture case without a detectable bone band was a 70-year-old woman with a fracture that had failed to unite and a total alkaline phosphatase of $9 \mathrm{KA}$ units/dl. In multiple myeloma with no osteoblastic activity and a normal alkaline phosphatase, no band was seen except for one case in which the bone band was no more than was found in the occasional normal adult patient mention 


\begin{tabular}{|c|c|c|c|c|c|c|c|c|c|}
\hline & \multirow[t]{2}{*}{ Type of Disease } & \multirow{2}{*}{$\begin{array}{l}\text { No. of } \\
\text { Cases }\end{array}$} & \multicolumn{7}{|c|}{ Alkaline Phosphatase Isoenzymes } \\
\hline & & & $\begin{array}{l}\text { Slow } \\
\text { Liver }\end{array}$ & $\begin{array}{l}\text { Fast } \\
\text { Liver }\end{array}$ & Bile & Intestine & Bone & Placenta & Regan \\
\hline Normals & $\begin{array}{l}\text { Adults } \\
\text { Growing children 3-12 years } \\
\text { Pregnancy-1st trimester } \\
\text { 2nd trimester } \\
\text { 3rd trimester }\end{array}$ & $\begin{array}{l}46 \\
21 \\
41 \\
29 \\
47\end{array}$ & $\begin{array}{l}46 \\
21 \\
41 \\
29 \\
47\end{array}$ & & & & $\begin{array}{r}6 \\
21\end{array}$ & $\begin{array}{r}3 \\
13\end{array}$ & \\
\hline \multicolumn{10}{|c|}{ (25) 250} \\
\hline Liver & $\begin{array}{l}\text { Infective hepatitis } \\
\text { Obstructive jaundice } \\
\text { (gallstones) } \\
\text { Primary biliary cirrhosis } \\
\text { Cirrhosis of the liver }\end{array}$ & $\begin{array}{l}38 \\
26 \\
42 \\
54\end{array}$ & $\begin{array}{l}38 \\
26 \\
42 \\
54\end{array}$ & $\begin{array}{l}4 \\
4 \\
2\end{array}$ & 3 & 12 & & & \\
\hline Intestinal & $\begin{array}{l}\text { Ulcerative colitis } \\
\text { Malabsorption syndrome } \\
\text { Coeliac disease } \\
\text { Duodenal ulcer }\end{array}$ & $\begin{array}{r}2 \\
9 \\
4 \\
22\end{array}$ & $\begin{array}{r}2 \\
9 \\
4 \\
22\end{array}$ & & & 1 & & & \\
\hline Bone & $\begin{array}{l}\text { Fractures } \\
\text { Rickets } \\
\text { Paget's disease } \\
\text { Multiple myeloma }\end{array}$ & $\begin{array}{r}10 \\
6 \\
3 \\
4\end{array}$ & $\begin{array}{r}10 \\
6 \\
3 \\
4\end{array}$ & & & & $\begin{array}{l}9 \\
6 \\
3 \\
1\end{array}$ & & \\
\hline Renal & $\begin{array}{l}\text { Chronic renal failure } \\
\text { Glomerulonephritis }\end{array}$ & $\begin{array}{r}12 \\
7\end{array}$ & $\begin{array}{r}12 \\
7\end{array}$ & & & 3 & 5 & & \\
\hline Primary malignant disease & $\begin{array}{l}\text { Liver } \\
\text { Lung } \\
\text { Bile duct } \\
\text { Pancreas } \\
\text { Breast } \\
\text { Prostrate } \\
\text { Colon } \\
\text { Vulva } \\
\text { Stomach } \\
\text { Tongue }\end{array}$ & $\begin{array}{r}3 \\
9 \\
15 \\
4 \\
6 \\
3 \\
2 \\
1 \\
1 \\
1\end{array}$ & $\begin{array}{r}3 \\
9 \\
15 \\
4 \\
6 \\
3 \\
2 \\
1 \\
1 \\
1\end{array}$ & 2 & 1 & & & & $\begin{array}{l}1 \\
1 \\
3\end{array}$ \\
\hline
\end{tabular}

Table I Serum alkaline phosphatase isoenzymes in normal subjects and in disease

found in the occasional normal adult patient mentioned earlier.

Patients with acute glomerulonephritis and pyelonephritis without uraemia had no abnormal band, whereas some patients with advanced chronic renal failure showed the intestinal band.

The sera from patients with malignant disease were particularly examined for Regan isoenzyme which was detected in six out of 45 miscellaneous cases. Of interest is its occurrence in three out of 15 cases of carcinoma of the bile duct, one of which also had fast-liver and bile isoenzymes.

We have not investigated chyle.

INTESTINAL ISOENZYME AND BLOOD GROUP Table II shows that the intestinal isoenzyme often

\begin{tabular}{llll}
\hline Blood Groups & $\begin{array}{l}\text { No. of Patients } \\
\text { (cirrhosis) }\end{array}$ & \multicolumn{2}{l}{ Isoenzymes } \\
\cline { 3 - 4 } & & Liver & Intestine \\
\hline O & 26 & 26 & 10 \\
A & 20 & 20 & - \\
AB & 6 & 6 & - \\
Total & 2 & 2 & 12 \\
\hline
\end{tabular}

Table II Alkaline phosphatase isoenzymes and blood groups demonstrable in cirrhosis is not present in patients with blood group A or AB. There were sufficiento group A patients for this to be significant.

\section{DIFFERENTIAL EFFECT OF INHIBITORS}

Table III confirms that various inhibitors can be used, mostly in conjunction with electrophoresis, for the identification of abnormal alkaline phos phatase isoenzymes.

\begin{tabular}{llll}
\hline Isoenzyme & $\begin{array}{l}\text { Heat }\left(65^{\circ} \mathrm{C}\right. \\
5 \text { min })\end{array}$ & $\begin{array}{l}\text { L-phenylalanine } \\
(5 \text { mmol/l) }\end{array}$ & $\begin{array}{l}\text { L-homoarginine } \\
(25 \text { mmol/l) }\end{array}$ \\
\cline { 2 - 4 } & Degree of Inhibition & \\
\hline Bone & ++++ & + & ++++ \\
Liver & ++ & + & ++++ \\
Intestine & + & ++++ & - \\
Placenta & - & ++++ & - \\
Regan & - & ++++ & - \\
\hline
\end{tabular}

Table III Effect of inhibitors on alkaline phosphatase isoenzymes

\section{Discussion}

In normal subjects, previous authors (Fritsche and Adams-Park, 1972) have found the slow $\left(\alpha_{2}\right)$ liver band with bone or intestinal band or both, while $\frac{\mathbb{\Phi}}{\mathbb{D}}$ 
Rhone and Mizuno (1973) have found only the slow $\left(\alpha_{2}\right)$ liver band in 19 out of 24 subjects. We have found only the slow $\left(\alpha_{2}\right)$ liver band in $\mathbf{4 0}$ out of 46 normal sera, the other six sera showing the slow $\left(\alpha_{2}\right)$ liver band and the bone band.

The regular finding in growing children between 3 and 12 years of age of a bone band in addition to the slow $\left(\alpha_{2}\right)$ liver band confirms the osteoblastic origin of the bone isoenzyme (Nagant de Deuxchaisnes and Krane, 1964). In normal pregnancy, the placental isoenzyme reaches its peak in maternal serum between 37 and 40 weeks at which time the growth of the microvilli declines rapidly (Fox, 1968; Fishman et al, 1972). We have found the placental isoenzyme most frequently in the third trimester of pregnancy, in nearly one-third of subjects.

There have been many detailed studies of the changes in serum alkaline phosphatases, both total and differential in abnormal pregnancy (Fishman and Ghosh, 1967; Fox, 1968; Fishman et al, 1972).

The first report of the intestinal band in cirrhosis was by Fishman, Inglis, and Krant (1965). Their patients were of blood groups $\mathrm{B}$ and $\mathrm{O}$ : other series (Kaplan and Rogers, 1969) have confirmed their finding. The intestinal band has been reported in normal subjects of blood groups $\mathbf{B}$ and $\mathbf{O}$ (Arfors et al, 1963; Bamford, Harris, Luffman, Robson, and Cleghorn, 1965): Beckmann (1964) related this to $\mathrm{ABH}$ secretor status. The presence of intestinal isoenzyme is also related to diet, the ingestion of fat elevating the intestinal isoenzyme level in the sera of blood group $\mathbf{O}$ secretor individuals (Langman, Leuthold, Robson, Harris, Luffman, and Harris, 1966; Walker, Eze, Tweedie, and Evans, 1971). This finding is in conformity with ours in 12 out of 54 cirrhotics showing the intestinal band, all 12 being of blood group $B$ or $O$. In two of our patients who were studied serially, the intestinal isoenzyme disappeared from serum as the aspartate transaminase and alkaline phosphatase returned towards normal. The finding of intestinal alkaline phosphatase in a suspected cirrhotic patient is confirmatory evidence of the diagnosis and may be useful in monitoring the course of the disease; absence of the isoenzyme has no diagnostic importance.

It is of interest that the intestinal isoenzyme was found in some cases of chronic renal failure, the total alkaline phosphatase being raised in all of these cases. The presence of the intestinal isoenzyme is unrelated to the plasma urea concentration but the patients are again of blood group B or $\mathbf{O}$. Further investigation of this finding is necessary. The presence of the bone isoenzyme found in chronic renal failure may be due to increased osteoblastic activity.

The fast $\left(\alpha_{1}\right)$ liver isoenzyme has been reported in a wide variety of hepatobiliary diseases whether primarily hepatocellular or primarily cholestatic (Korner, 1962; Taswell and Jeffers, 1963; Rhone and Mizuno, 1973) and this has been our experience. It is completely unrelated to total alkaline phosphatase and its presence, although it indicates hepatobiliary disease, is of no diagnostic or prognostic importance.

Bile isoenzyme has previously been reported in the serum of cases of primary biliary cirrhosis (Kaplan and Rogers, 1969); it was found here in cases of primary biliary cirrhosis and of carcinoma of the bile duct, one of which also had the slow and fast liver bands. It was never detected in obstructive jaundice from other causes and its significance is unknown.

Detection of a definite bone band is an established method of assessing increased osteoblastic activity (Nagant de Deuxchaisnes and Krane, 1964). It is practicable in the presence of an increased liver band, and may be useful as an index of active bone repair, for example, in assessing the union of fractures. Electrophoresis is as simple as, and more specific than, separation of the isoenzyme by heat (Posen, Neale, and Clubb, 1965). Many like to measure a separate enzyme whose serum activity increases in cholestasis but not in bone disease, eg, $5^{\prime}$ nucleotidase or $\gamma$-glutamyltranspeptidase, the latter being more sensitive but less specific for disease of the liver (Whitfield, Pounder, Neale, and Moss, 1972).

The nature of the Regan isoenzyme has been widely discussed in recent years (Fishman, 1973). The incidence of three in 15 cases of carcinoma of the bile duct is much higher than reported in tumours generally (Fishman et al, 1968) and this isoenzyme, though found in tumour tissue of carcinoma of bile duct (Jacoby and Bagshawe, 1971) has not been reported before in the serum in this condition.

We thank our clinical colleagues for access to case material.

\section{References}

Aoba, H., Hariu, Y., and Yamaguchi, R. (1967). Serum heat-stable alkaline phosphatase in normal and abnormal pregnancy. Tohoku J. exp. Med., 91, 201-207.

Arfors, K. E., Beckman, L., and Lundin, L. G. (1963). Further studies on the association between human serum phosphatase and blood groups. Acta genet. (Basel), 13, 366-368.

Bamford, K. F., Harris, H., Luffman, J. E., Robson, E. B., and Cleghorn, T. E. (1965). Serum alkaline phosphatase and the ABO blood groups. Lancet, 1, 530-531.

Beckman, L. (1964). Associations between human serum alkaline phosphatase and blood groups. Acta genet. (Basel), 14, 286-297.

Canapa-Anson, R., and Rowe, D. J. F. (1970). Electrophoretic separation of tissue specific alkaline phosphatases. J. clin. Path., 23, 499-508.

Fishman, W. H. (1973). Carcinoplacental isoenzyme antigens. Advanc. Enzyme Regulat., 11, 293-321.

Fishman, W. H., Bardawil, W. A., Habib, H. G., Anstiss, C. L., and Green, S. (1972). The placental isoenzyme of alkaline phosphatase in sera of normal pregnancy. Amer. J. clin. Path., 57, 65-74. 
Fishman, W. H., and Ghosh, N. K. (1967). Isoenzymes of human alkaline phosphatase. Advanc. Clin. Chem., 10, 255-370.

Fishman, W. H., Inglis, N. I., and Krant, M. J. (1965). Serum alkaline phosphatase of intestinal origin in patients with cancer and with cirrhosis of the liver. Clin. chim. Acta, 12, 298-303.

Fishman, W. H., Inglis, N. I., Stolbach, L. L., and Krant, M. J. (1968). A serum alkaline phosphatase isoenzyme of human neoplastic cell origin. Cancer Res., 28, 150-154.

Fox, H. (1968). Villous immaturity in the term placenta. Obstet. and Gynec., 31, 9-12.

Fritsche, H. A., Jr., and Adams-Park, H. R. (1972). Cellulose acetate electrophoresis of alkaline phosphatase isoenzymes in human serum and tissue. Clin. Chem., 18, 417-421.

Green, S., Cantor, F., Inglis, N. R., and Fishman, W. H. (1972). Normal serum alkaline phosphatase isoenzymes examined by acrylamide and starch gel electrophoresis and by isoenzyme analysis using organ specific inhibitors. Amer. J. clin. Path., $57,52-64$.

Inglis, N. R., Fishman, L., Stolbach, L. L., Warshaw, J. B., and Fishman, W. H. (1972). A comparison of chyle isoenzymes of alkaline phosphatase in chyle and hypophosphatasemic sera. Clin. chim. Acta, 38, 67-73.

Jacoby, B., and Bagshawe, K. D. (1971). Placental-type alkaline phosphatase from human tumour tissue. Clin. chim. Acta, 35, 473-481.

Kaplan, M. M., and Rogers, L. (1969). Separation of human serumalkaline phosphatase isoenzymes by polyacrylamide gel electrophoresis. Lancet, 2, 1029-1031.

Korner, N. H. (1962). Distribution of alkaline phosphatase in serum protein fractions. J. clin. Path., 15, 195-199.

Langman, M. J. S., Leuthold, E., Robson, E. B., Harris, J., Luffman,
J. E., and Harris, H. (1966). Influence of diet on the 'intestinal' component of serum alkaline phosphatase in people of different ABO blood groups and secretor status. Nature (Lond.), 212, 41-43.

Moss, D. W. (1966). A note on spectrophotometric estimation of alkaline phosphatase activity. Enzymologia, 31, 193-202.

Nagant de Deuxchaisnes, C., and Krane, S. M. (1964). Paget's disease of bone: clinical and metabolic observations. Medicine (Baltimore), 43, 233-266.

Posen, S., Neale, F. C., and Clubb, J. S. (1965). Heat inactivation in the study of human alkaline phosphatases. Ann. intern. Med., 62, 1234-1243.

Rhone, D. P., and Mizuno, F. M. (1973). Profiles of alkaline phosphatase isoenzymes in serum, using cellulose acetate electrophoresis and organ specific inhibitors. Amer. J. clin. Path., $59,531-541$.

Smith, I., Lightstone, P. J., and Perry, J. D. (1968). Separation of human tissue alkaline phosphatases by electrophoresis on acrylamide disc gels. Clin. chim. Acta, 19, 499-505.

Stevens, J., and Thomas, F. (1972). Alkaline phosphatase: reaction rate analysis at $340 \mathrm{~nm}$. Clin. chim. Acta, 37, 541-543.

Taswell, H. F., and Jeffers, D. M. (1963). Isoenzymes of serum alkaline phosphatase in hepatobiliary and skeletal disease. Amer. $J$. clin. Path., 40, 349-356.

Walker, B. A., Eze, L. C., Tweedie, M. C. K., and Evans, D. A. P. (1971). The influence of ABO blood groups, secretor status and fat ingestion on serum alkaline phosphatase. Clin. chim. Acta, 35, 433-444.

Whitfield, J. B., Pounder, R. E., Neale, G., and Moss, D. W. (1972). Serum $\gamma$-glutamyltranspeptidase activity in liver disease. Gut, 13, 702-708. 